\title{
Influential Factors on Customers' Satisfaction of Rural ICT Offices: A Case Study of Lordegan Township in Iran
}

\author{
Bijan Khalil-Moghaddam ${ }^{1, *}$ \\ ${ }^{1}$ Department of Management, Faculty of Human Sciences, Shahrekord branch, Islamic Azad University, Shahrekord, \\ Iran \\ *Correspondence: Department of Management, Faculty of Human Sciences, Shahrekord branch, Islamic Azad \\ University, Shahrekord, Iran. E-mail: bijan_khm@yahoo.com
}

Received: December 24, 2018

Accepted: January 16, 2019 Online Published: January 20, 2019

doi:10.5430/sass.v6n1p17

URL: https://doi.org/10.5430/sass.v6n1p17

\begin{abstract}
Rural ICT offices (Centers) are one of the initiatives of ICT department in Iran for fulfillment of the rural development process via ICT. Success and effectiveness of these offices depend on the customers' satisfaction regarding the received services. This paper as the one of the first studies in the field of "customers' satisfaction of rural ICT offices" in Iran and the first one in Chahar Mahal va Bakhtiari Province attempts to identify the factors affecting customer satisfaction of ICT offices services in Lordegan Township as a part of Chahar Mahal va Bakhtiari Province. The sample included 39 rural ICT offices (As sample unit) and 272 individuals (As observational unit), who were selected by proportional cluster random sampling method. Survey method was used, and the data was analyzed by correlation and multiple regression techniques. Based on the regression models related to the young and middle-aged groups, 3 variables showed to have significant impact on customers' satisfaction of rural ICT offices in Lordegan Township (Complexity, relative advantage, and educational level) and about the old group, it is deduced that the variable of compatibility has a significant impact on the dependent variable. According to the results, through removing the weaknesses of ICT offices the rural satisfaction of ICT offices can be reinforced.
\end{abstract}

Keywords: customers' satisfaction, rural ICT offices, Lordegan Township, Iran

\section{Introduction}

The remoteness of official organizations from most of the Iran rural settings and insufficient income in companion with lack of communication technology have resulted in poverty, powerlessness and huge rural-to-urban migration (Khalil-Moghaddam \& Khatoon-Abadi, 2013: 1083-1094). Poverty reduction in all its forms especially in rural settings is determined as a key goal and strategy in most of document of future perspectives in global level such as Sustainable Development Goals (UNDP, 2015: 15). In this regard, in Iran the national Spatial Planning as one of the most important upstream documents has emphasized on removing the exclusion from rural settings with the aim of maintenance of producer stratum. (MPO, 2015). Access to rural ICT as a part of citizens' life (Lemoine \& Ramsey., 2011) in different countries such as: India, Malaysia, Philippines, Nepal, and Mongolia, with their positive effects on socio-economic and cultural indices of rural areas have approved the high capacities of ICT in removing the distances between rural and urban areas and concequently in remaining rural population, and poverty alleviation (Harris, 2004: 51-66).

Access to ICT involves more than availability; it also includes affordability and adoption (Hudson, 2013). Based on the latest results of the census of Iranian Internet users (2016), the household internet penetration rate for rural settings versus urban settings in Iran is in a low and weak status (Respectively 36.7\% and 62.1\%) (Statistical Center of Iran, 2018). On the other hand, according to Khalil-Moghaddam's study (2008) ICT adoption in rural ICT centers of Iran (As one of the most famous forms of sharing access) had not been affected by the economic variables of the users. Therefore, the forms of sharing access could be as suitable solutions for developing the ICT sevices in rural areas with poor and low income population such as: Rural areas in Iran (Khalil-Moghaddam, 2008: 51-76). Access to technologies is likely to be some forms of shared access, perhaps through existing institutions such as: Public libraries or post offices, or through the creation of new institutions such as: Multi-purpose community tele-centres. Sharing 
access is exclusively generated in developing countries such as: Villag Information Shops, Keltron Information Kiosks and Thandarai Telecentre in India, Multipurpose Community Telecentres in Philippines, Internet Centres in Mongolia, and Nepal Telecentre Pilot Project in Nepal (Harris, 2004).

While ICTs are often viewed as necessary for the survival and growth of rural areas, all forms of communications are important (Bruce \& Delury, 2006; Ramsey \& Moss, 2009). "Rural ICT offices" as one of the initiatives of ICT Ministry of Iran is the known form of communications and shared access and the counter for E-Government play a significant role in rural development processes. Establishing 10000 rural ICT offices through the rural areas in Iran was one of the important goals of the $3^{\text {rd }}$ National Development Program (Iranian Ministry of Interior, 2013). At this time there are 8638 active rural ICT offices in Iran (Telecommunication Company of Iran, 2016), 157 in Chahar Mahal va Bakhtiari Province, as well as 44 in Lordegan Township (Telecommunication Company of Chahar Mahal va Bakhtiari Province, 2018). The main goals of rural ICT offices are: 1) presenting the integrated informative\&communicative services to villages and remote areas, 2) preparing the necessary contexts for emersion of E-government, E-banking, E-tourism, and Tele-working in rural and remote areas (Karim Aghaei, Amiri \& Fath pour, 2009: 8-9). Rural ICT offices present services such as: Information Technology services (For instance E-mail, download, internet registration, and information services), communication services (For example fax, fixed telephone line, and cell phone), post services, as well as post-bank services.

So as to bridge the digital divide between urban and rural settings, improve the rural development indices, and alleviate the poverty by rural ICT offices, the sustainability of offices is a critical necessity. Sustaining the service delivery as one of four types of sustainability that apply to shared access centers (Colle \& Roman, 2001) depends on customers' satisfaction of rural ICT offices. Therefore, it is so essential that a suitable framework for the first time be presented for understanding, analyzing and evaluating the customer satisfaction of rural ICT offices in Iran especially in undeveloped provinces and townships such as: Chahar Mahal va Bakhtiari, and Lordegan.

\section{The Case Study Area}

Lordegan Township as the study area is located in the southern part of Chahar Mahal va Bakhtiari Province which is located in the southwestern part of Iran (Figure 1). This Township covers 342000 hectars and lies between latitudes 30' and 55" to $31^{\prime}$ and $26^{\prime \prime}$ and longitudes $49^{\prime}$ and $50^{\prime \prime}$ to $34^{\prime}$ and $26^{\prime \prime}$. The mentioned Township with the population of 209681 people, 5 towns (Including Lordegan, Monj, Malkhalifeh, Sardasht and Alooni), 5 districts (Central, Monj, Felard, Roodasht and Khanmirza), 11 subdistricts, and 363 rural areas is the most crowded Township in Chahar Mahal va Bakhtiari Province regarding rural population (With a 73\% rural population). (Statistical Center of Iran, 2018). The status of Lordegan Township regarding ICT indices is relatively inappropriate. The index of established fixed telephone lines penetration rate for Chahar Mahal va Bakhtiari Province, Lordegan Township, and rural settings of Lordegan Township in 2018 was $30.4 \%, 19.2 \%$, and $19.7 \%$ respectively. Also the status of index of active fixed telephone lines penetration rate for the 3 mentioned situations is reported $28.8 \%, 14 \%$, and $13.1 \%$ respectively. It is notable that 44 rural ICT offices are serving rural population of Lordegan Township to enhance the rural ICT status (Telecommunication Company of Chahar Mahal va Bakhtiari Province, 2018).
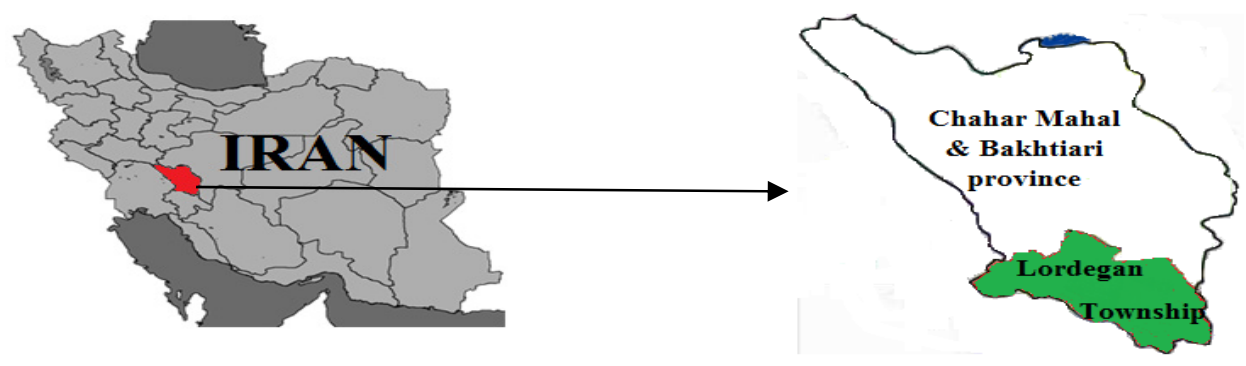

Figure 1. Position of Lordegan Township Study Area in Chahar Mahal va Bakhtiari Province and Iran 


\section{Literature Review}

During the past decade, the concepts of customer satisfaction have gained increasing importance in both online and off-line businesses (Lin et al., 2011). Customer satisfaction generally means customer reaction to the state of fulfilment, and customer judgment of the fulfilled state (Oliver, 1997). In general, the models for measuring the customer satisfaction devide into objective and subjective types. In the first type, the customer satisfaction is evaluated according to the related rates and indeces, and in the second one it is estimated based on the customer's perceptions (Toepfer, 1999: 68-71). Subjective models are used in 2 different methods namely event-based and feature-based methods (Stauss, 1995: 62-78). In the feature-based methods, satisfaction is measured based on the mental (Subjective) assessment of the abstract chractristics driven from organizations' or companys' performance. In the mentioned methods, ordinal measurments could be used for assessment (Toepfer, 1999). The feature-based methods could be applied into 2 formats namely explicit and implicit that the first one is better due to using the monodimensional or multidimensinoal measurements (Hayes \& Dredge, 1998: 206-229). The main factor determining customer satisfaction is the customers' own perceptions of performance (Zeithaml, Berry \& Parasuraman, 1996: 31-46). The most widely accepted conceptualization of the customer satisfaction concept is the Expectancy Disconfirmation Theory that expresses that satisfaction level is a result of the difference between expected and perceived performance (McQuitty, Finn, \& Wiley, 2000).

On the one hand because the most popular models and studies in the field of rural ICT focuses on the influential factors on the successful adoption of ICT, and on the other hand, because users' satisfaction of ICT is found as a main factor can affects the ICT adoption so studying the influential factors on users' satisfaction of rural ICT offices is an essential issue. Several studies have been conducted to understand customer satisfaction of services related to ICT. Most of these studies have emphasized that the customer satisfaction is the main important mediate goal for mentioned service providers on their way to obtaining economic success. In the following, the extant related studies are demonstrated. The case studies show that in the field of "customers' satisfaction of Electronic services" only two main contexts including bank systems and urban areas have been studied, but the rural areas were rarely studied. So, the present study is one of the first studies in the field of "customers' satisfaction of rural ICT offices" in Iran and the first one in Chahar Mahal va Bakhtiari Province. Asadpoor et al. (2017) in their study showed that the E-Service Quality has positive and direct effect on satisfaction of Saderat Bank's customers. Also the Availability, Security, Reliability and Fulfillment are direct impact but personalization has no effect on customer satisfaction (Asadpoor \& Abolfazli, 2017). Al-Hawary \& Al-smeran (2017) found that the Electronic Service Quality (Ease of use, Web Site Design, privacy, and Responsiveness) affected Customers' Satisfaction of Islamic Banks in Jordan (Al-Hawary et al., 2017). Addai, Bismark, Eric \& Quaye (2015) by a multiple regression analysis showed that there is a positive correlation between customer satisfaction and e-baking availability, reliability and convenience in the selected banks in Ghana (Addai et al, 2015). Because the mentioned independent variables in researches for Asadpoor et al, Al-Hawary et al, and Addai et al, were estimated according to the customers' perceptions about E-Services as innovation, so we can call them as innovation characteristics. Khalil-Moghaddam et al. (2013) in their study showed that there isn't any correlation between household's satisfaction towards the user's ICT use and amount of ICT adoption (Khalil-Moghaddam et al, 2013). Yaghoubi et al. (2011) according to the hierarchical structure of customers' satisfaction dimensions (Multicriteria Satisfaction Analysis) used by Mihelis et al. (2001) justified a set of criteria and sub-criteria for customers' satisfaction of ICT offices in Iran. The 5 criteria studied, are satisfaction of staff (such as skills, knowledge and responsibility), type of services (such as cost), delivery of Service (such as the waiting time, the accuracy of service delivery), access (such as number of staff and working hours) and image (such as reputation) (Yaghoubi, Haghi \& Khazaee Asl, 2011). Rasekhi, Rahimi, \& Ali Beygi (2011) evaluated the influential factors on the satisfaction of rural population with rural ICT centers in Kermanshah Township in Iran. According to the results of mentioned research, 45 percent of rural population was satisfied with ICT centers and variables such as: Age and average usage level of rural ICT offices a month were found influential positively. Beside variables such as: Educational level, income, personal computer ownership and number of children have had negative impacts on the rural customers' satisfaction (Rasekhi et al., 2011: 56-71). Lopez, Valenzuela, Ignacio, Caldero'n, Velasco \& Fajardo (2011) conducted a telephone survey of patients referred to a realtime telemedicine consultation at the telehealth Centre in Bogota. Results showed that $80 \%$ of the respondents were satisfied or very satisfied with the teleconsultation services. More than $50 \%$ believed that telemedicine had a positive effect in terms of time- and cost-savings. Cognitive factors were identified as influential factors of patient's satisfaction (Lopez et al., 2011: 83-87). Based on the mentioned work, relative advantage as one of the Innovation characteristics will be considered as an independent variable in the present paper.

Post and post bank. Co (2010) showed 97\% of villagers' customers in Iran use at least one of the services presented in 
rural ICT offices. The average of customers' satisfaction of rural ICT offices was between $40 \%$ and $70 \%$. The referral average of villagers' customers to the nearest city has been reduced to $1 / 3$ due to the services of rural ICT offices (Telecommunication Company of Iran, 2010). According to the mentioned study, relative advantage (Effect of ICT offices on the rural-to-urban migration) as one of the innovation characteristics will be considered as an independent variable in the present paper. Denga et al. (2010) examined the determinants of customer satisfaction of Mobile Instant Message (MIM) services in China. The findings revealed that perceived service quality, perceived customer value contribute to generating customer satisfaction with MIM. The results also showed that age and gender have moderating effects (Denga, Lua, Weib, \& Zhanga, 2010: 289-300). Lin, Wu, Hsueh-Ying \& Chang (2011) according to a multiple regression showed that online consumers' satisfaction was positive and significant affected by information quality, system quality, service quality, product quality, delivery quality and perceived price (Lin et al., 2011: 276-281). Terakemeh (2010) studied the villagers' satisfaction of rural ICT offices in Hormozgan Province, Iran. The results showed that there was a relative satisfaction with mentioned offices performance, and there was not a significant relationship between satisfaction level of ICT offices services and variables: age, gender, marital, and educational level (Terakemeh, 2010).

In this research, due to the complexity and intangibility perceived by rural people about presented services by rural ICT offices, and on the other hand, because of the importance of multidimentional and mixed nature of satisfaction feeling, the subjective model, feature-based methods (Explicit), and multidimensinoal measurements were used. Also according to the case studies, beside the perceived performance (Based on Expectancy Disconfirmation Theory) which affect the levels of satisfaction, it is necessary the other variables (such as demographical characteristics) as moderator factors be studied. Therefore in the present paper, the conceptual model (Figure 2) results from a combination of the theories, models and related case studies clustering the influencing factors into two main categories including: 1) customers' perceptions about services delivered by ICT offices and 2) demographical characteristics involving individual, social and economic characteristics of customers. Since the e-services provided by rural ICT offices are as a package of innovations, so the customers' perceptions about this innovation must be addressed based on the Innovation characteristics (Relative advantage, image, observe ability, compatibility, subjective norms and complexity). In fact, the conceptual model expresses that customers of rural ICT offices with various demographical characteristics will have different perceptions about ICT in general and rural ICT offices services in particular (Innovation characteristics) that consequently affect the gap between their expectations, and rural ICT offices' performance, and finally the various level of customers' satisfaction. In the present research, the total customers' satisfaction of rural ICT offices in Lordegan Township is estimated based on 5 dimensions of satisfaction including 1) satisfaction of staff, 2) satisfaction of telecommunication services, 3) satisfaction with services related to cell phone bills, 4) satisfaction with services of fixed telephone line bills, and 5) satisfaction of time table.

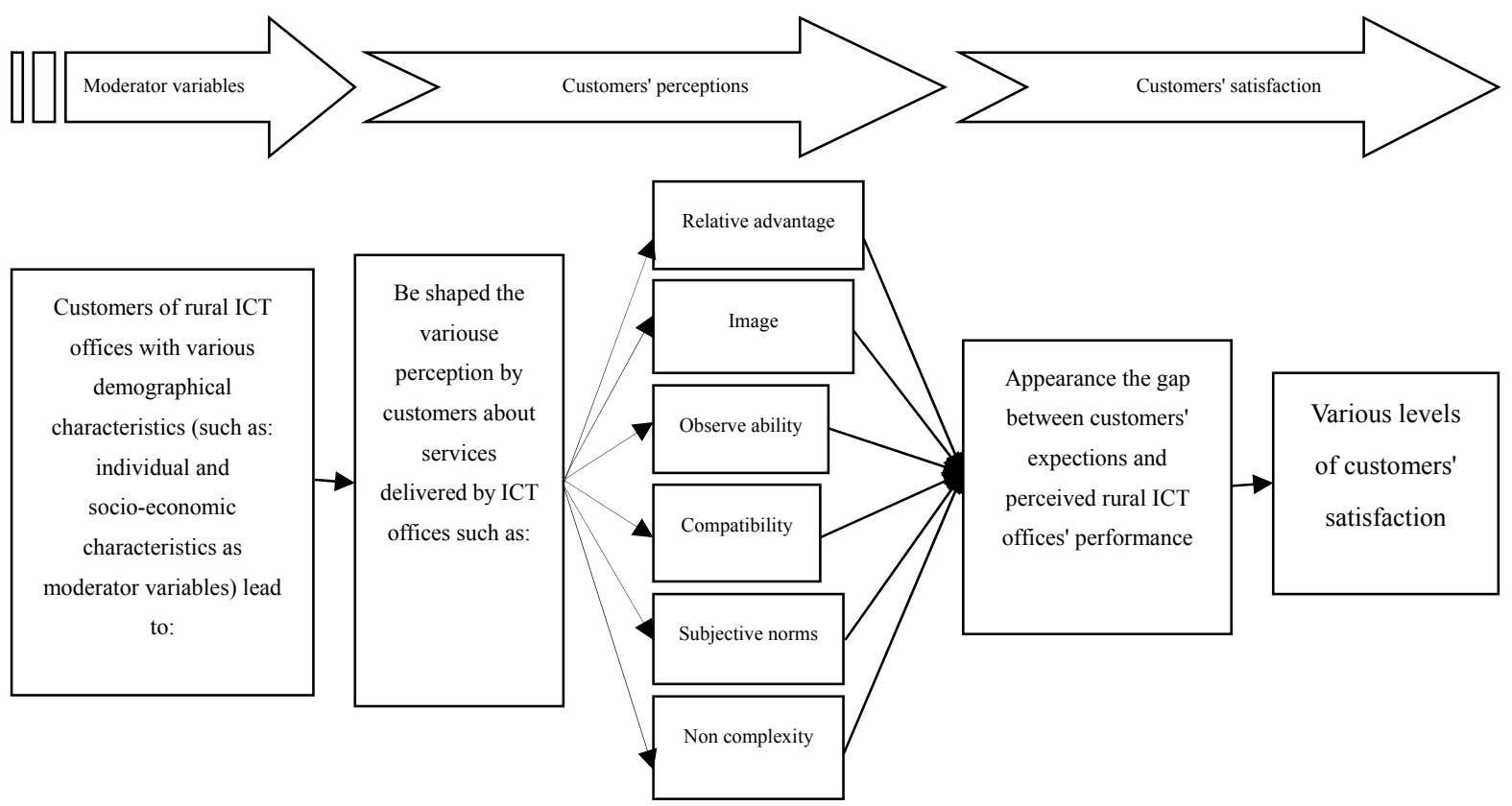

Figure 2. A Conceptual Model for Customers' Satisfaction of Rural ICT Offices 
The following research hypotheses are resulted from the conceptual model:

Hypothesis 1: There is a relationship between the customer's individual characteristics and customer's satisfaction of rural ICT offices.

Hypothesis 2: The rural ICT offices customer's individual characteristics have impacts on customer's satisfaction of rural ICT offices.

Hypothesis 3: There is a relationship between the customers' households' economic characteristics, and customer's satisfaction of rural ICT offices.

Hypothesis 4: The ICT offices customers' households' economic characteristics have impacts on customer's satisfaction of rural ICT offices.

Hypothesis 5: There is a relationship between the rural ICT offices customers' households' social characteristics, and customer's satisfaction of rural ICT offices.

Hypothesis 6: The rural ICT offices customers' households' social characteristics have impacts on customer's satisfaction of rural ICT offices.

Hypothesis 7: There is a relationship between the innovation characteristics of the customers, and customer's satisfaction of rural ICT offices.

Hypothesis 8: The innovation characteristics of the customers have impacts on customer's satisfaction of rural ICT offices.

\section{Material and Methods}

This part comprised of survey research was accompanied by correlation and regression analyses. A questionnaire based on Likert spectrum (That is sequential multiple level responses) was used to collect the data. Interpretative statistics has been used to determine the influencing extent of the parameters. The qualitative variables (Through statistical and weighting techniques in Factor Analysis) were converted into the semi quantitative data by SPSS20. Statistically, it is justified to use the analytical methods and tests for semi quantitative variables as similar to quantitative variables. Also the different correlation analyses along with the multiple regression with stepwise method were used for each variable couples depending on the type of data (Kalantari, 2012: 121). The statistical society included Villagers customers from 44 rural ICT offices use ICT offices services once a season at least in Lordegan Township as a part of Chahar Mahal va Bakhtiari Province territory (Table 1). The probability cluster random sampling method (Proportionate to size) was used to provide context for generalizing data. The sample size determined by Cochran's formula (Saraie, 1993: 57) is 272. In table 2, Cronbach Alpha and KMO (Kaiser-Meyer-Olkin) figures for the respectively reliability and validity of the used concepts have been demonstrated. The scores of Cronbach Alpha indicate acceptable values. KMO is a statistical criterion by which the external validity of the applied concepts (Variables) in the questionnaire is measured. The KMO figure representing $87 \%$ and more shows that a phrase or a word would have a homogenous concept among the respondents. In the present research, customers' satisfaction of rural ICT offices in Lordegan Township is assessed as the dependent variable.

Table 1. The Levels of Reliability and the KMO Figures for the Applied Concepts Validity

\begin{tabular}{cccc}
\hline Districts & $\begin{array}{c}\text { Number of rural ICT } \\
\text { offices }\end{array}$ & $\begin{array}{c}\text { Sample of rural ICT offices } \\
\text { (As sample units) }\end{array}$ & $\begin{array}{c}\text { Sample of customers of offices } \\
\text { (As observational units) }\end{array}$ \\
\hline Central & 14 & 13 & 86 \\
Monj & 7 & 6 & 42 \\
Roodasht & 4 & 3 & 26 \\
Khanmirza & 9 & 8 & 55 \\
Felard & 10 & 9 & 63 \\
Township & 44 & 39 & 272 \\
\hline
\end{tabular}

Source: The research findings 
Table 2. The Levels of Reliability and the KMO Figures for the Applied Concepts Validity

\begin{tabular}{|c|c|c|c|c|c|}
\hline Factors & Items & $\begin{array}{c}\text { Cronbach } \\
\text { Alpha }\end{array}$ & K.M.O. & $\begin{array}{l}\text { Bartlett's } \\
\text { Test }\end{array}$ & Sig \\
\hline \multirow{2}{*}{$\begin{array}{c}\text { The individual } \\
\text { (Villager customer) }\end{array}$} & $\begin{array}{l}\text { The villager customer's } \\
\text { knowledge of the computer } \\
\text { and internet (Digital literacy) }\end{array}$ & .923 & $88 \%$ & 1537.354 & .000 \\
\hline & $\begin{array}{l}\text { The level of villager } \\
\text { customer's satisfaction }\end{array}$ & .966 & $93 \%$ & 6476.358 & .000 \\
\hline Innovation & The innovation characteristics & .901 & $87 \%$ & 3953.252 & .000 \\
\hline
\end{tabular}

Source: The research findings

\section{Results and Discussion}

\subsection{Descriptive Data}

According to research results $64 \%$ of rural ICT offices customers are males. The customer's age ranges between 17 to 68 years (Average: 30.3 ) among whom $41.8 \%$ are single. Customers with higher educational level include $40 \%$ (Either having a college degree or attended college) and $8.4 \%$ of them are illitrate. Among the customers, $7.6 \%$ are students, $12.7 \%$ are house keepers, and $6.9 \%$ are farmers. $38.16 \%$ of rural ICT offices customers are with a low level of digital literacy (Knowledge and skill in computer and internet), 23.23\% of them are at a medium level and the rest are with a high level of digital literacy. Meanwhile, $93 \%$ of all customers are satisfied regarding the studied offices at a medium or upper than medium level. On the other hand, due to the differences between classes of customers, it is notable that entire customers are categorized in 3 groups named young group (Age of 18 to 35), middle-aged group (36 to 50), and old group (+50), and consequently the status of customers' satisfaction in 3 different groups is presented in table 3 . Based on the result the young group is more satisfied than middle-aged group and also the old group is less satisfied than the 2 mentioned groups.

Table 3. Customers' Satisfaction of Rural ICT Offices of Lordegan Township Separately 3 Groups

\begin{tabular}{llccc}
\hline \multicolumn{1}{c}{ Groups } & \multicolumn{1}{c}{$\begin{array}{c}\text { Levels of } \\
\text { satisfaction }\end{array}$} & Frequency & $\begin{array}{c}\text { Percentage of } \\
\text { Frequency }\end{array}$ & $\begin{array}{c}\text { Cumulative } \\
\text { Percentage }\end{array}$ \\
\hline Young group & Very high (Upper 4 and to 5) & 83 & 41.5 & 41.5 \\
& High (Upper 3 and to 4) & 57 & 28.5 & 70 \\
& Medium (Upper 2 and to 3) & 51 & 25.5 & 95.5 \\
& Low (Upper 1 and to 2) & 7 & 3.5 & 99 \\
& Very low (1) & 2 & 1.0 & 100 \\
Middle-aged group & Sum & 200 & 100 & 61.7 \\
& Very high (Upper 4 and to 5) & 37 & 61.7 & 83.3 \\
& High (Upper 3 and to 4) & 13 & 21.6 & 93.3 \\
& Medium (Upper 2 and to 3) & 6 & 10.0 & 98.3 \\
& Low (Upper 1 and to 2) & 3 & 5.0 & 100 \\
& Very low (1) & 1 & 1.7 & 100 \\
Old group & Sum & 60 & 50.0 & 50.0 \\
& Very high (Upper 4 and to 5) & 6 & 25.0 & 75.0 \\
& High (Upper 3 and to 4) & 3 & 16.7 & 91.7 \\
& Medium (Upper 2 and to 3) & 2 & 8.3 & 100 \\
& Low (Upper 1 and to 2) & 1 & 0 & 100 \\
\hline
\end{tabular}

Source: The research findings 


\subsection{The Two Variable Analysis}

Table 4. Correlation between the Independent Variables and the Customers' Satisfaction regarding Rural ICT offices of Lordegan Township

\begin{tabular}{|c|c|c|c|c|c|c|c|c|}
\hline \multirow[b]{2}{*}{ Factors } & \multirow[b]{2}{*}{ Variable } & \multirow{2}{*}{$\begin{array}{c}\text { Type of } \\
\text { Correlation }\end{array}$} & \multicolumn{2}{|c|}{ Young group } & \multicolumn{2}{|c|}{ Middle-aged group } & \multicolumn{2}{|c|}{ Old group } \\
\hline & & & $\begin{array}{c}\text { The correlation } \\
\text { value }\end{array}$ & Sig & $\begin{array}{c}\text { The correlation } \\
\text { value }\end{array}$ & Sig & $\begin{array}{c}\text { The correlation } \\
\text { value }\end{array}$ & Sig \\
\hline \multirow{6}{*}{$\begin{array}{l}\text { Customer's } \\
\text { individual }\end{array}$} & Age & $\mathrm{P}$ & $* * 0.175$ & 0.000 & Ns 0.200 & 0.063 & ${ }^{\mathrm{Ns}} 0.056$ & 0.432 \\
\hline & $\begin{array}{r}\text { Digital literacy } \\
\text { (Knowledge and skill } \\
\text { in computer and } \\
\text { internet) }\end{array}$ & $\mathrm{P}$ & $* * 0.173$ & 0.007 & Ns -0.131 & 0.159 & Ns -0.215 & 0.251 \\
\hline & Job & $\mathrm{L}$ & Ns 0.088 & 0.262 & Ns 0.064 & 0.284 & Ns 1.339 & 0.255 \\
\hline & Gender & $\mathrm{C}$ & Ns 0.134 & 0.313 & Ns 0.322 & 0.101 & ${ }^{\mathrm{Ns}} 0.522$ & 0.351 \\
\hline & Marital status & $\mathrm{C}$ & Ns 0.098 & 0.597 & Ns 0.141 & 0.754 & Ns 0.420 & 0.183 \\
\hline & Educational level & $\mathrm{S}$ & $* *-0.192$ & 0.003 & $* *-0.377$ & 0.001 & Ns -0.146 & 0.326 \\
\hline \multirow{9}{*}{$\begin{array}{c}\text { Customer's } \\
\text { households' } \\
\text { economic } \\
\text { characteristics }\end{array}$} & Ownership of house & $\mathrm{C}$ & Ns 0.081 & 0.733 & Ns 0.268 & 0.229 & ${ }^{\mathrm{Ns}} 0.212$ & 0.654 \\
\hline & $\begin{array}{l}\text { Ownership of more } \\
\text { than one house }\end{array}$ & $\mathrm{C}$ & Ns 0.120 & 0.460 & Ns 0.223 & 0.425 & Ns 0.559 & 0.290 \\
\hline & $\begin{array}{l}\text { Amount of irrigated } \\
\text { land holding (ha) }\end{array}$ & $\mathrm{P}$ & Ns -0.009 & 0.448 & Ns -0.015 & 0.455 & Ns 0.100 & 0.379 \\
\hline & $\begin{array}{l}\text { Amount of rainfed } \\
\text { land holding (ha) }\end{array}$ & $\mathrm{P}$ & Ns 0.104 & 0.071 & Ns 0.041 & 0.379 & Ns 0.077 & 0.406 \\
\hline & $\begin{array}{r}\text { Amount of irrigated } \\
\text { land under cultivation }\end{array}$ & $\mathrm{P}$ & Ns 0.011 & 0.439 & Ns -0.004 & 0.486 & Ns 0.067 & 0.418 \\
\hline & $\begin{array}{r}\text { Amount of rainfed } \\
\text { land under cultivation }\end{array}$ & $\mathrm{P}$ & $* 0.143$ & 0.021 & Ns 0.039 & 0.383 & Ns 0.077 & 0.406 \\
\hline & $\begin{array}{r}\text { Number of owning } \\
\text { livestock }\end{array}$ & $P$ & Ns 0.099 & 0.082 & Ns 0.145 & 0.135 & Ns -0.240 & 0.226 \\
\hline & $\begin{array}{r}\text { Current cost of cell } \\
\text { phone }\end{array}$ & $\mathrm{P}$ & Ns 0.012 & 0.431 & Ns 0.030 & 0.410 & Ns -0.319 & 0.156 \\
\hline & $\begin{array}{r}\text { Current cost of fixed } \\
\text { telephone line }\end{array}$ & $P$ & Ns 0.050 & 0.242 & Ns 0.115 & 0.191 & Ns 0.420 & 0.087 \\
\hline \multirow{4}{*}{$\begin{array}{l}\text { Customer's } \\
\text { households' } \\
\text { social related } \\
\text { characteristics }\end{array}$} & $\begin{array}{r}\text { Number of } \\
\text { household's members }\end{array}$ & $P$ & Ns -0.042 & 0.279 & Ns 0.120 & 0.180 & Ns -0.405 & 0.096 \\
\hline & $\begin{array}{r}\text { Percent of household's } \\
\text { literates }\end{array}$ & $\mathrm{P}$ & $* *_{-} 0.172$ & 0.008 & Ns -0.093 & 0.239 & Ns -0.222 & 0.244 \\
\hline & $\begin{array}{l}\text { Existence of } \\
\text { household's members } \\
\text { with formal } \\
\text { occupation }\end{array}$ & $\mathrm{C}$ & Ns 0.102 & 0.559 & $* 0.381$ & 0.033 & Ns 0.697 & 0.120 \\
\hline & $\begin{array}{l}\text { Number of } \\
\text { household's members } \\
\text { with formal } \\
\text { occupation }\end{array}$ & $\mathrm{P}$ & Ns -0.042 & 0.279 & $* *-0.352$ & 0.003 & Ns -0.323 & 0.153 \\
\hline \multirow{6}{*}{$\begin{array}{c}\text { Innovation } \\
\text { characteristics }\end{array}$} & Relative advantage & $\mathrm{P}$ & $* *-0.447$ & 0.000 & $* *-0.604$ & 0.000 & Ns -0.284 & 0.186 \\
\hline & Compatibility & $\mathrm{P}$ & $* *-0.337$ & 0.000 & $* *-0.440$ & 0.000 & $* *-0.752$ & 0.002 \\
\hline & Non complexity & $\mathrm{P}$ & $* *-0.474$ & 0.000 & $*_{-}-0.250$ & 0.027 & Ns 0.187 & 0.280 \\
\hline & Image & $\mathrm{P}$ & $* *-0.262$ & 0.000 & $*_{-0.295}$ & 0.011 & Ns -0.027 & 0.467 \\
\hline & Observe ability & $\mathrm{P}$ & $* *-0.436$ & 0.000 & $* *-0.503$ & 0.000 & Ns -0.307 & 0.166 \\
\hline & Subjective norms & $\mathrm{P}$ & Ns 0.109 & 0.062 & $*-0.228$ & 0.040 & Ns 0.185 & 0.283 \\
\hline
\end{tabular}

Source: The research data. $* *: 1 \%$ significance level, $*: 5 \%$ significance level, Ns: nonlinear significant relationship.

$\mathrm{P}=$ Pearson, $\mathrm{S}=$ Spearman, $\mathrm{C}=$ Cramer's $\mathrm{V}$, and $\mathrm{L}=$ Lambda 
To test the relationship between the independent variables and the dependent variable (Customers' satisfaction regarding rural ICT offices), the Pearson, Spearman, Cramer's V and Lambda analyses could be applied (Kalantari, 2012). Based on table 4, for young group there is a significant relationship between the customers' satisfaction of rural ICT offices and, variables of age, digital literacy, and educational level. Also regarding middle-aged group there is a significant relationship between the dependent variable and independent variable of educational level. But for the old group there is not any significant relationship between the dependent and independent variables. Thus, hypothesis 1 is accepted for variables of age, digital literacy, and educational level in young group, and for mere variable of educational level in middle-aged group. According to table 4, no variable of the customers' households' economic factor, has a significant relationship with 'customers' satisfaction of rural ICT offices' in the middle-aged and the old groups, but there is a significant relationship between the dependent and independent variable of "amount of rainfed land under cultivation" in the young group. Therefore hypothesis 3 is accepted only for mentioned variable in young group. With regard to the correlation quotients (Pearson, and Cramer's V), there is a significant relationship between the variable of 'Percent of household's literates', and 'customers' satisfaction of rural ICT offices' in the young group, and a significant relationship between the variables of 'existence of household's members with formal occupation' and 'number of household's members with formal occupation' and dependent variable in the middle-aged group and no relationship between independent and dependent variables in the old group. Therefore hypothesis 5 is accepted mere for mentioned variables in the young and middle-aged groups, but for the other independent variables (Being indicated in table 4), is rejected. It is notable that according to the Pearson correlation coefficient, there is a significant negative relationship between the all of innovation variables except subjective norms, and 'customers' satisfaction of rural ICT offices' in the young group, and also between all of innovation variables and dependent variable in the middle-aged group, as well as between independent variable of compatibility and dependent variable in the old group. Hence, hypothesis 7 is accepted for the mentioned variables in every 3 groups.

\subsection{Multiple Variable Analysis}

As a result of the two variable analyses, in young group, middle-aged group, as well as old group respectively 10, 9 and 1 independent variables proved to have a significant relationship with customers' satisfaction of rural ICT offices. Only the mentioned variables related to every 3 groups were entered in the 3 regression models. The results of the multiple regressions analyses with stepwise method have been shown in tables 5 and 6.

Table 5. Multiple Regression Analysis to Identify the Effective Factors on the Customers' Satisfaction of Rural ICT Offices of Lordegan Township

\begin{tabular}{clcccc}
\hline Groups & \multicolumn{1}{c}{ Variable } & Beta & S.E & B & Sig \\
\hline \multirow{5}{*}{ Young group } & $\begin{array}{l}\text { Constant coefficient } \\
\text { X1: Non complexity (As one of the }\end{array}$ & ---- & 0.233 & 5.564 & 0.000 \\
& $\begin{array}{l}\text { Innovation characteristics) } \\
\text { X2: Relative advantage (As one of the }\end{array}$ & -0.299 & 0.058 & -0.343 & 0.000 \\
& $\begin{array}{l}\text { Innovation characteristics) } \\
\text { X3: Educational level }\end{array}$ & -0.162 & 0.016 & -0.044 & 0.006 \\
\hline \multirow{5}{*}{$\begin{array}{c}\text { Middle-aged } \\
\text { group }\end{array}$} & $\begin{array}{l}\text { Constant coefficient } \\
\text { X1: Relative advantage (As one of the }\end{array}$ & ----- & 0.331 & 6.203 & 0.000 \\
& $\begin{array}{l}\text { Innovation characteristics) } \\
\text { X2: Educational level }\end{array}$ & -0.449 & 0.204 & -0.841 & 0.000 \\
& $\begin{array}{l}\text { X3: Non complexity (As one of the } \\
\text { Innovation characteristics) }\end{array}$ & -0.226 & 0.108 & -0.217 & 0.049 \\
\hline \multirow{2}{*}{ Old group } & $\begin{array}{l}\text { Constant coefficient } \\
\text { X1: Compatibility (As one of the }\end{array}$ & ----- & 0.512 & 5.560 & 0.000 \\
& Innovation characteristics) & -0.752 & 0.307 & -1.107 & 0.005 \\
\hline
\end{tabular}

Source: The research data 
Table 6. The Result of the Stepwise Multiple Regression Model Assessment to Identify the Effective Factors on the Customers' Satisfaction of Rural ICT Offices of Lordegan Township

\begin{tabular}{lccccc}
\hline \multicolumn{1}{c}{ Groups } & $\mathrm{R}$ & $\mathrm{R}^{2}$ & Adjusted $\mathrm{R}^{2}$ & $\mathrm{~F}$ & Sig.F \\
\hline Young group & 0.587 & 0.344 & 0.334 & 34.335 & 0.000 \\
Middle-aged group & 0.693 & 0.481 & 0.453 & 17.279 & 0.000 \\
Old group & 0.752 & 0.565 & 0.522 & 13.006 & 0.005 \\
\hline
\end{tabular}

Source: The research data

Based on the regression models related to the young and middle-aged groups (Table 5), only 3 variables showed to have significant impact on customers' satisfaction of rural ICT offices in Lordegan Township (Complexity, relative advantage, and educational level). Thus, regarding the young and middle-aged groups, hypotheses 2 and 8 are accepted for only the mentioned variables, and hypotheses 4 and 6 are rejected. According to the old group's regression model, it is deduced that merely one variable (Compatibility) has a significant impact on the dependent variable. Thereupon about the old group, hypothesis 8 is accepted for only the mentioned variable, and hypotheses 2, 4 and 6 are rejected. It is notable that all effective variables in 3 groups have had negative impacts on customers' satisfaction of rural ICT offices. Generally the quantity of relative advantage, and non complexity as 2 of the innovation characteristics imply the usage level of innovation such as: Rural ICT offices services, and sequently in a higher level of usage of innovation rather than in a lower one, there is a higher relative probability for perceiving the difficulties, weaknesses, and challenges, and at the same time, amount of satisfaction of the mentioned innovation probably reduced because of a low quality in provided services. On the other hand, the level of education affects positively the customers' perception about the relative advantage, and non complexity and consequently has a negative effect on the satisfaction level. According to the amount of Beta coefficients related to the young and middle-aged groups (Table 5) the most influential variable was respectively 'complexity' and 'relative advantage'. The orientation of the entire independent variables in 3 regression models, determine respectively $34.4 \%, 48.1 \%$, and $56.5 \%$ of the variance of customers' satisfaction of rural ICT offices as dependent variable $\left(R^{2}=0.344,0.481\right.$ and 0.565$)$. Based on the amounts of B coefficients for independent variables (Table 5) that predict variances of dependent variable assuming constant the other independent variables, it's clear that the variable of 'relative advantage' have the most power of prediction for variances of customers' satisfaction of rural ICT offices in the young and the middle-aged groups. The figures of S.E est $_{\text {est }}$ (Standard Error for estimation) (Table 5), imply that the accuracy level of line regression in estimating the amount of customers' satisfaction of rural ICT offices for the young group is more suitable than 2 others. The significance of an appropriate quantity of $\mathrm{R}^{2}$ of regression models (Table 6) as well as proving the significance of regressions via statistic of F, imply the 'goodness of fit' of the regression every 3 models of research.

\section{Conclusion and Recommendations}

This work studied the determinants of customers' satisfaction of rural ICT offices in Lordegan Township of Iran. The results showed that young and middle-aged rural customers' satisfaction with ICT offices was affected by the customers' perceptions about rural ICT offices services namely innovation characteristics (Relative advantage, and non complexity) and by educational level. It could be concluded that rural young and middle-aged customers with an appropriate level of education, are probably relatively more acquainted with advantages, positive effects and non complexity of ICT in general and rural ICT offices services in particular. Consequently, the amount of adoption and use of services provided in rural ICT offices will increase. And thereupon probably due to the low quality of services, the gap between their expectations and perceived rural ICT offices' performance will be widened, and sequently the level of customers' satisfaction will decrease. About the old group, it is proved that only variable of 'compatibility' has had a negative impact on the dependent variable. A probable reason could be expressed is that as the perceived compatibility between compounents of local culture and structure and function of rural ICT offices services increases, the adoption and use of E-services increases, and ultimately while the quality of E-services is inappropriate, it leads to a lower satisfaction due to experiencing more weaknesses related to the mentioned E-services. In fact, it seems that the quality of E-services presented to the people is unsuitable. Based on the research findings, the following recommendations are proposed to enhancing the customers' satisfaction of rural ICT offices through further development of rural ICT offices within rural communities and fostering more research in the area:

1) The economic status of majority of rural areas in Iran in general and specially in Chahar Mahal va Bakhtiari 
Province and Lordegan Township is weak. On the other hand, the regression analysis showed that rural customers' satisfaction with ICT offices had not been affected by the customers' economic variables. Therefore, it is recommended that the quantity and quality of Rural ICT offices as the best initiative for fulfillment of the rural development process via ICT in Iran must be enhanced.

2) It is suggested that a comprehensive set of rural ICT offices' services that every 3 groups use separately mostly, be identified by a requisite need assesment, and ultimately a making qualitative process for them be taken as priority by relevant agencies.

3) Due to the negative impact of education level on the satisfaction in the young and middle-aged groups, it is recommended that in the process of planning such as requisite need assessment, most of focus be emphasized on more educated people.

4) Based on the common result that mentions that probably the quality of E-services presented to the people is unsuitable, enhancing the quality of the services by provider agencies such as Iranian Ministry of ICT and the Telecommunication Company of Chahar Mahal va Bakhtiari Province and Lordegan Township is a vital necessity.

\section{References}

Addai, Bismark., Ameyaw, Bismark., Ashalley, Eric., \& Quaye, Isaac. (2015). Electronic Banking and Customer Satisfaction: Empirical Evidence from Ghana. British Journal of Economics, Management \& Trade, 9(3), 1-8. https://doi.org/10.9734/BJEMT/2015/19269

AL-HAWARY, Ibraheem Shelash., \& AL-SMERAN, Warda Fares. (2017). Impact of Electronic Service Quality on Customers Satisfaction of Islamic Banks in Jordan Sulieman. International Journal of Academic Research in Accounting, Finance and Management Sciences, 7(1), 170-188. https://doi.org/10.6007/IJARAFMS/v7-i1/2613

Asadpoor, Saeedeh \& Abolfazli, Abolfazl. (2017). Effect of Electronic Service Quality on Customer Satisfaction and Loyalty Saderat Bank’s Customers. International Journal of Scientific Study, 5(4), 407-411.

Bruce, D., K. Ellis \& Delury, N. (2006). The role and impact of community newsletters in fostering social cohesion and community development. Journal of Rural and Community Development, 2(1), 176-185.

Colle, R. D., \& R. Roman. (2001). Modules for Training Telecentre Staffs. An Interim Report with Sample Modules, Cornell University. Retrieved from http://www.itu.int/ITU-D/univ_access/telecentres/documents/ModTrainingTelecStaff.pdf

Denga, Zhaohua., Lua, Yaobin,. Weib, Kwok Kee., \& Zhanga, Jinlong. (2010). Understanding customer satisfaction and loyalty: An empirical study of mobile instant messages in China. International Journal of Information Management, 30, 289-300. https://doi.org/10.1016/j.jinfomgt.2009.10.001

Governership of Chahar Mahal va Bakhtiari Province, Planning Deputyship. Socio-economic report of Chahar Mahal va Bakhtiari Province, 2011. (2012). 209-210.

Harris, R. W. (2004). Information and Communication Technologies for Poverty Alleviation. United Nations Development Program, Asia-Pacific Development Information Program (UNDPAPDIP). 51-66. (Has translated into Persian version by Khatoon-Abadi, Ahmad, and Khalil-Moghaddam, Bijan at 2010).

Hayes, J., \& Dredge, F. (1998). Managing customer service. Hampshire, Gower Publishing, 206-229. Retrieved from http://www.sciencedirect.com/

Hudson, E., E. (2013). Beyond Infrastructure: Broadband for Development in Remote and Indigenous Regions. In W. Ashton \& A. S. Carson (Eds.), [Special issue]. The Journal of Rural and Community Development, 8(2), 44-61.

Iranian Minisrty of Interior. (2013). 3th National development progam of Islamic Republic of Iran.

Kalantari, K. (2012). Data processing and analysis in socio-economic research [bookinPersian] (5th ed.).Tehran: Farhange Saba Press. 121.

Karim Aghaei, Sanaz., Amiri \& Fath pour. (2009). New services of Information Technology in rural. Telecommunication Company of Fars Province. 8-9.

Khalil-Moghaddam, Bijan \& Khatoon-Abadi, Ahmad. (2013). Factors affecting adoption of ICT among rural users a case study of ICT Center in Iran. Telecommunication Policy, 37(11), 1083-1094. https://doi.org/10.1016/j.telpol.2013.02.005 
Khalil-Moghaddam, Bijan, Khatoon-Abadi, Ahmad \& Kalantari, Khalil. (2008). Study the influencing factors on amount of Information and Communication Technology (ICT) adoption in comprehensive center for ICT services of Gharnabad in Golestan Province. Rural and Development Journal, 11(3), 51-76. (In Persian).

Lemoine, Michelle., \& Ramsey, Doug. (2011). Digital Youth: ICT use by young people in rural southwestern Manitoba. Prairie Perspectives: Geographical Essays, Vol: 14. edited by Alec Aitken, Mohammad Kamal and Bob Patrick.

Lin, Chun-Chun., Wu, Hsueh-Ying \& Chang, Yong-Fu. (2011). The critical factors impact on online customer satisfaction. Procedia Computer Science, 3, 276-281. https://doi.org/10.1016/j.procs.2010.12.047

Lo'pez, Catalina., Valenzuela, Jose' Ignacio., Caldero'n, Jorge Enrique., Velasco, Andre's Fabia'n \& Fajardo, Roosevelt. (2011). A telephone survey of patient satisfaction with realtime telemedicine in a rural community in Colombia. Journal of Telemedicine and Telecare, 17, 83-87. https://doi.org/10.1258/jtt.2010.100611

Management and Planning Organization of Iran (MPO). 2015. National Criteria of Spatial Planning. (In Persian). Retrieved from: http://rc.majlis.ir/fa/law/show/124494

McQuitty, S., Finn, A., \& Wiley, J. B. (2000). Systematically Varying Customer Satisfaction and its Implications for Product Choice. Academy of Marketing Science Review.

Mihelis, G., E. Grigoroudis, Y. Siskos, Y. Politis \& Y. Malandrakis. (2001). Customer satisfaction measurement in the private bank sector, European Journal of Operational Research, 130(2), 347-360. https://doi.org/10.1016/S0377-2217(00)00036-9

Oliver, R. L. (1997). Satisfaction: A behavioral perspective on the consumer. Boston: Irwin McGraw-Hill.

Ramsey, Doug \& Moss, A. (2009). The use of the traditional media in the new rural economy. Zeitschrift für Kanada-Studien, 29(2), 107-131.

Rasekhi, Behrouz, Rahimi, Azar \& Ali Beygi, Amir Hossein. (2012). Assessing the influential factors on the rural satisfaction of rural ICT offices: A case study of Kermanshah Province. Journal of Agricultural Extension and Education Research, 4(4), 56-71.

Saraie, H. (1993). Introduction to Sampling Methods, in Research. (Book in Persian). Samt Press. 57.

Statistical Center of Iran. (2018). The results of the census of Internet users- 2016. (In Persian). Retrieved from http://www.amar.org.ir/Portals/0/Files/abstract/1389/n_IT_89.pdf

Stauss, B. (1995). Instants of the truth in the service production your relevance and their measurement with the help of the edge contact analysis. Journal of Service Industry Management, 6(2), 62-78. https://doi.org/10.1108/09564239510146915

Telecommunication Company of Chahar Mahal va Bakhtiari Province. (2018). http://tci-chba.ir/portal.

Telecommunication Company of Iran, Virtual Systems Processing Co. (2008). Counseling services for providing 10000 rural to rural ICT offices. Reports 1 to 4, Tehran, ICT Ministry of Iran. P 16.

Telecommunication Company of Iran. (2016). Retrieved from http://tci.ir

Terakemeh, Babak. (2010). Measuring the villagers' satisfaction of rural ICT offices' performance in Hormozgan Province. Retrieved fro http://ictquik.blogfa.com

Toepfer, A. (1999). Customer satisfaction measure and increase (2nd Ed.). Germany, Luchterhand Publishing House, pp. 68-71.

United Nations Development Programme. (2015). Human Development Report 2015: Work for Human Development. 15.

Yaghoubi, Nour Mohammad., Haghi, Atiyeh \& Khazaee Asl, Sadegh. (2011). E-Government and Citizen Satisfaction in Iran: Empirical Study on ICT Offices. World Applied Sciences Journal, 12(7), 1084-1092.

Zeithaml, V. A., Berry, L. L., \& Parasuraman, A. (1996). The behavioral consequences of service quality. Journal of Marketing Research, 60(2), 31-46. 